\title{
Promising directions of technological development and the use of digital technologies in dairy farming
}

\author{
$Y$. Ivanov and I. Tikhomirov* \\ Federal State Budgetary Scientific Institution "Federal Scientific Agroengineering Center VIM", 108823 Moscow, Russia
}

\begin{abstract}
Nowadays, special attention is paid to increasing the sustainability and competitiveness of dairy cattle breeding, which is due to the need to accelerate the growth of its own milk production to ensure the country's food security. Among the priority areas for the industry development, many researchers highlight the modernization of the material and technical base by updating fleet of machinery, technological equipment, introducing innovative methods of managing production processes and using modern technologies. An analysis of the current state and the use of technical and technological potential of the industry showed that the bulk of milk produced in agricultural organizations falls on the already morally and physically outdated enterprises that use high-cost extensive production technologies, characterized by low labor productivity. The share of dairy farms with less than 100 cows was $68.9 \%$, while mega-farms account for only $0.3 \%$ of the facilities. Small-scale enterprises play a leading role in the livestock of the milking herd. In such farms, $28.7 \%$ of cows are kept on a tethered housing system. As a rule, no adequate feeding of animals is provided. However, in terms of the level of milk productivity and product volume, large-scale dairy complexes are currently in the lead with a herd of more than 800 heads at a time, where milk yield per fodder cow exceeds $5000 \mathrm{~kg}$ of milk. Considering that the largest number of dairy herds is concentrated on farms with a population of 100 to 200 cows, we consider the most expedient and promising way to improve the efficiency and competitiveness of these enterprises to modernize them technological re-equipment using domestic digital technologies and mechanization means.
\end{abstract}

\section{Introduction}

The development of the agricultural sector in modern economic conditions requires the development of effective approaches to carry out technical and technological modernization of the industry, ensuring the intensification of agricultural production to saturate the domestic market and realize the export potential of the agro-industrial complex.

At present, special attention is paid to increasing sustainability and competitiveness of dairy cattle breeding, which is due to the high proportion of imported dairy products in the domestic market and the need to accelerate the growth of domestic milk production to ensure the country's food security.

Among the priority areas for the development of the industry, leading scientists and experts highlight modernization of the material and technical base by updating fleet of equipment, technological equipment, introducing innovative methods of managing production processes and using modern technologies and principles of the digital economy.

The purpose of the study is to develop approaches and proposals for intensification of technological modernization and the use of digital technologies in dairy farming.

\section{Material and research methods}

The research studies the state of technological development and the level of updating material and technical base of dairy cattle breeding in Russia. It summarizes the experience of using information systems and applying digital technologies in the industry.

This study analyses materials of scientific and technical literature on the issues under consideration. The article keeps updating the current state of agroengineering services, the material and technical base of dairy cattle breeding and the experience of introducing modern information and analytical systems in the management and control over the implementation of technological processes.

To solve the tasks set, the article uses special research methods, such as a monographic method, expert assessments, system analysis, etc.

\section{Research results and discussion}

In recent years, the sector has shown a tendency for an annual increase in milk production in agricultural organizations and peasant (farmer) households.

*Corresponding author: tikhomirov958@gmail.com 
Table 1. Development of dairy farming in the Russian Federation

\begin{tabular}{|l|c|c|c|c|c|c|c|c|}
\hline \multicolumn{1}{|c|}{ Index } & $\mathbf{2 0 1 3}$ & $\mathbf{2 0 1 4}$ & $\mathbf{2 0 1 5}$ & $\mathbf{2 0 1 6}$ & $\mathbf{2 0 1 7}$ & $\mathbf{2 0 1 8}$ & $\mathbf{2 0 1 9}$ & $\mathbf{2 0 1 9}$ to 2013, \% \\
\hline Livestock of cows, thousand heads & 8.4 & 8.3 & 8.1 & 8.0 & 8.0 & 7.9 & 8.0 & 95.2 \\
\hline - in agricultural organizations & 3.5 & 3.4 & 3.4 & 3.4 & 3.3 & 3.3 & 3.3 & 94.3 \\
\hline - in households & 3.9 & 3.8 & 3.6 & 3.4 & 3.4 & 3.4 & 3.3 & 84.6 \\
\hline - in peasant (farming) households & 1.0 & 1.1 & 1.1 & 1.2 & 1.2 & 1.3 & 1.4 & 140.0 \\
\hline Milk production, million tons & 29.9 & 30.0 & 29.9 & 29.8 & 30.2 & 30.6 & 31.3 & 104.7 \\
\hline - in agricultural organizations & 14.0 & 14.4 & 14.7 & 15.1 & 15.7 & 16.2 & 17.0 & 121.4 \\
\hline - in households & 14.0 & 13.7 & 13.2 & 12.6 & 12.1 & 11.9 & 11.7 & 83.6 \\
\hline - in peasant (farming) households & 1.8 & 1.9 & 2.0 & 2.2 & 2.4 & 2.5 & 2.6 & 144.4 \\
\hline
\end{tabular}

Table 2. Efficiency of milk production depending on the concentration of cows [2]

\begin{tabular}{|c|c|c|c|c|c|c|c|c|c|c|c|}
\hline \multirow[b]{2}{*}{ Index } & \multicolumn{10}{|c|}{ Livestock of cows at the dairy complex } & \multirow[b]{2}{*}{ Total } \\
\hline & $100>$ & $\begin{array}{c}101 \\
-200\end{array}$ & $\begin{array}{c}201- \\
400\end{array}$ & $\begin{array}{c}401- \\
600\end{array}$ & $\begin{array}{c}601- \\
800\end{array}$ & $\begin{array}{l}801- \\
1000\end{array}$ & $\begin{array}{l}1001- \\
1200\end{array}$ & $\begin{array}{l}1201- \\
1600\end{array}$ & $\begin{array}{l}1601- \\
2400\end{array}$ & 2401 & \\
\hline Number of complex & 13417 & 1838 & 1888 & 966 & 527 & 301 & 158 & 197 & 115 & 68 & 19475 \\
\hline Specific weight, $\%$ & 68.9 & 9.4 & 9.7 & 5.0 & 2.7 & 1.5 & 0.8 & 1.0 & 0.6 & 0.3 & 100 \\
\hline Livestock of cows, $\mathrm{t}$ & 1306 & 364 & 755 & 575 & 411 & 286 & 174 & 276 & 230 & 170 & 4547 \\
\hline Specific weight, \% & 28.7 & 8.0 & 16.6 & 12.6 & 9.0 & 6.3 & 3.8 & 6.1 & 5.1 & 3.7 & \\
\hline Milk from 1 cow, $\mathrm{kg}$ & \multicolumn{3}{|c|}{3130} & \multicolumn{4}{|c|}{4000} & \multicolumn{3}{|c|}{5000} & \\
\hline Milk production, thousand tons & 4077 & 1139 & 2364 & 2299 & 1644 & 1430 & 869 & 1379 & 1150 & 850 & 17200 \\
\hline Specific weight, \% & 23.7 & 6.6 & 13.8 & 13.4 & 9.6 & 8.3 & 5.1 & 8.0 & 6.7 & 4.9 & 100 \\
\hline Applied technology & \multicolumn{10}{|c|}{\begin{tabular}{c|c|c}
$\begin{array}{c}\text { Tethered content, } \\
\text { inadequate feeding }\end{array}$ & $\begin{array}{c}\text { Mixed type of housing an } \\
\text { feeding }\end{array}$ & $\begin{array}{c}\text { Loose housing, balanced } \\
\text { feeding }\end{array}$ \\
\end{tabular}} & \\
\hline
\end{tabular}

In 2019, the total milk production in all categories of farms amounted to 31.3 million tons, of which 17.0 million tons or $54.3 \%$ fell on the share of agricultural organizations, which is $4.7 \%$ or 7.5 percentage points more than the level of 2013 (tab. 1).

The increase in production volumes was accompanied by a $4.8 \%$ reduction in the number of cows to 8.0 million heads, incl. in industrial cattle breeding by $5.7 \%$ to 3.3 million heads and in private backyards by $15.4 \%$ to 3.3 million heads. The development of the farming movement and active state grant support for the creation of livestock farms led to an increase in the number of dairy herds in peasant (farm) households by $40.0 \%$ to 1.4 million heads, but this did not compensate for the overall drop in livestock.

One of the priority directions of the development of dairy cattle breeding is the improvement of the organization of production, the optimal location of production facilities and the renewal of the material and technical base through the introduction of modern resource-saving technologies and equipment [1].

Analysis of the current state and the use of the technical and technological potential of the industry showed that the bulk of milk produced in agricultural organizations falls on the already morally and physically outdated enterprises that use high-cost extensive production technologies, characterized by low labor productivity (Table 2).

The share of dairy farms with less than 100 cows was $68.9 \%$, while mega-farms account for only $0.3 \%$ of the facilities. Small-scale enterprises play a leading role in the livestock of the milking herd. In such farms, $28.7 \%$ of cows are kept on a tethered housing system. As a rule, no adequate feeding of animals is provided.
However, in terms of the level of milk productivity and the volume of products, large-scale dairy complexes are currently in the lead with a livestock of more than 800 heads bred at a time, where the milk yield per fodder cow exceeds $5000 \mathrm{~kg}$ of milk.

This technology provides loose housing and the organization of balanced feeding with complete feed mixtures.

Considering that the largest number of dairy herds is concentrated on farms with a population of 100 to 200 cows, we consider the most expedient and promising direction to increase the efficiency and competitiveness of these enterprises to modernize them - technological re-equipment domestic digital technologies and mechanization means.

It should be noted that in different regions of our country, different systems of maintenance and technologies of milk production are common. This is due to both available technological potential, the state of local labor market development and the price situation in the dairy market (Table 3 ).

In particular, the current favorable price situation on the market in the Central Federal District stimulated the construction of modern and modernization of existing dairy farms, which ensured a decrease in the share of the use of extensive technology of tethered housing and the transition to loose housing, with the feeding of balanced feed mixtures and the provision of qualified machine milking of cows in specialized premises.

On the contrary, in the regions of the Siberian Federal District with lower selling prices for milk and a strong territorial remoteness between production and processing enterprises, a less favorable situation has developed, which does not allow obtaining an acceptable amount of profit for resource support for the 
implementation of the modernization program and renewal of the material and technical base.

In this regard, an urgent direction of technological development is substantiation of approaches and creation of measures to modernize the industry and reduce the capital intensity of production.

In our opinion, the introduction of modern resourcesaving technologies should be considered as a priority task, the fulfillment of which is the key to further sustainable development of the material and technical base of dairy cattle breeding and the domestic milk market.

One of the key areas of modernization of the industry today is the use of information technologies and the principles of precision animal husbandry, based on electronic identification, control and management of technological processes at all stages of production [4].

Table 3. The state of the material and technical base of dairy cattle breeding [2]

\begin{tabular}{|c|c|c|c|c|c|c|c|c|}
\hline \multirow{3}{*}{ Region } & \multicolumn{8}{|c|}{ Applied technology } \\
\hline & \multicolumn{2}{|c|}{ keeping, \% } & \multicolumn{2}{|c|}{ feeding, $\%$} & \multicolumn{4}{|c|}{ milking, \% } \\
\hline & tethered & loose & $\begin{array}{c}\text { separate } \\
\text { distribution }\end{array}$ & feed mixture & $\begin{array}{c}\text { in } \\
\text { buckets }\end{array}$ & $\begin{array}{c}\text { nto the milk } \\
\text { pipe }\end{array}$ & $\begin{array}{r}\text { milking } \\
\text { parlor }\end{array}$ & robot \\
\hline Russia & 62.8 & 37.2 & 31.2 & 68.8 & 8.9 & 60.6 & 29.4 & 1.1 \\
\hline $\begin{array}{l}\text { Central } \\
\text { Federal } \\
\text { District }\end{array}$ & 51.5 & 48.5 & 27.3 & 72.7 & 6.4 & 48.8 & 43.0 & 1.8 \\
\hline $\begin{array}{l}\text { Volga } \\
\text { Federal } \\
\text { District } \\
\end{array}$ & 67.1 & 32.9 & 28.9 & 71.1 & 12.4 & 59.6 & 27.4 & 0.6 \\
\hline $\begin{array}{l}\text { Northwe } \\
\text { stern } \\
\text { Federal } \\
\text { District }\end{array}$ & 60.1 & 39.9 & 27.2 & 72.8 & 5.8 & 54.8 & 36.5 & 2.9 \\
\hline $\begin{array}{l}\text { Ural } \\
\text { Federal } \\
\text { District }\end{array}$ & 71.9 & 28.1 & 24.9 & 75.1 & 2.3 & 70.7 & 25.5 & 1.5 \\
\hline $\begin{array}{l}\text { Siberian } \\
\text { Federal } \\
\text { District }\end{array}$ & 79.3 & 20.7 & 33.5 & 66.5 & 11.8 & 72.4 & 15.6 & 0.2 \\
\hline $\begin{array}{l}\text { Far } \\
\text { Eastern } \\
\text { Federal } \\
\text { District } \\
\end{array}$ & 58.6 & 41.4 & 41.7 & 58.3 & 15.4 & 60.2 & 22.2 & 2.2 \\
\hline $\begin{array}{l}\text { Southern } \\
\text { federal } \\
\text { district }\end{array}$ & 46.9 & 53.1 & 9.1 & 90.9 & 14.5 & 53.8 & 41.7 & - \\
\hline $\begin{array}{l}\text { North } \\
\text { Caucasus } \\
\text { Federal } \\
\text { District }\end{array}$ & 55.3 & 44.7 & 80.1 & 19.9 & 9.5 & 80.4 & 9.1 & 1.0 \\
\hline Europe & 15.0 & 85.0 & 25.0 & 75.0 & 5.0 & 30.0 & 60.0 & 5.0 \\
\hline USA & 3.0 & 97.0 & 3.0 & 97.0 & 1.0 & 7.0 & 84.0 & 8.0 \\
\hline
\end{tabular}

Currently, the most widespread systems in dairy cattle breeding are systems for identifying and monitoring the physiological state and level of productivity of animals, which control the eatability and structure of the individual diet, average daily milk yield and weight gain, fitness activity, etc.

Another group includes information and analytical systems for microclimate control, mechanization and automation of the most labor-intensive processes, such as milking, feeding, manure removal and providing a standardized microclimate.

The introduction of these systems makes it possible to increase the efficiency of resource use and the quality of manufactured products, reduce the labor intensity of production and the need for personnel, thereby solving the acute problem of a shortage of highly qualified labor resources in rural areas [5].

The basis for the administration of digital control systems for technological processes in dairy cattle breeding is to ensure strict identification of all bred livestock, the organization of a single register for accounting and control over the vital activity and productivity of each individual animal on the farm.

As a result of the collection and processing of the information received, the article forms a unified database, which includes information about the age, physiological status and health of the animal. This data makes it possible to draw up an individual plan for the feeding of cows, their maintenance and veterinary services. 
The availability of such information makes it possible to plan the productivity of the herd, as well as to ensure adequate feeding of animals, taking into account the individual characteristics of development and to increase the efficiency of the use of feed resources.

The automatic identification system includes special devices for recognizing an individual animal, which can function and use various physical principles of communication (radio engineering, optical, magnetic, and acoustic or induction). As a rule, the device is attached to the collars of the animal and acts as a responder; the recognition system works on the principle of pulse code modulation. After reading, the recognized unique number of a particular individual is transferred to a single database for registration [6].

In addition, special ear tags and bolus-shaped gastric capsules are used, which create a magnetic field and thereby transmit information to the scanner and enter the computer via a wireless connection for further processing.

Highly efficient automatic milk meters, built into robotic milking systems of cows, which control the main technological parameters in the process of milking a cow (live weight, temperature, electrical conductivity, etc.) are of great relevance [7, 8]. They also allow you to determine various stages of lactation, periods of heat in cows, the number of somatic cells, their motor activity and other parameters of zootechnical registration.

In this regard, monitoring the state of milk herd productivity and express analysis of milk is a key condition for effective milk production and the competitiveness of the industry.

Express analysis of the milk of each animal allows you to reliably assess the state of health and productivity. The processing of the obtained data makes it possible to control the level of productivity and identify problems arising during the performance of technological operations, as well as ensure timely adjustments to the rations, service and maintenance of technological equipment.

Another important direction of control and management of technological processes is the achievement of target indicators of productive longevity and fertility of the herd, which play a decisive role in ensuring expanded reproduction and profitability of dairy cattle breeding.

The ability of dairy cattle to reproduce offspring and the period of its productive use are not only the most important economic and biological qualities, but also key factors that determine the economic efficiency of milk production and the level of technological development of dairy cattle breeding.

Currently, there are various technological platforms on the market for solving this problem, which make it possible to organize electronic accounting and registration of large amounts of information based on the identification of the bred livestock.

For example, the ISBC group of companies has developed an identification system based on RFID tags, which allows receiving data from an animal throughout its life and creating an individual electronic passport.
RFID (Radio Frequency IDentification) technology is a radio-frequency identification that automatically identifies objects, including those that are at a distance, using radio signals to track their movement. You can put certain information on an RFID tag, save it, and later read it.

It should be noted that RFID tags are more reliable and durable than classical means of animal identification and make it possible to generate a larger amount of information and simplify the reading process, because this technology does not require its location in the immediate vicinity of the scanner.

The principle of operation of the system is to transfer information to a single base from the chip when animals cross the reading zone, which makes it possible to reduce the processing time and increase their reliability, as well as reduce the likelihood of errors when entering data into the farm information system [4].

The world's leading manufacturers of technological equipment and robotic equipment for dairy cattle breeding offer their customers a package software product that includes not only information systems that ensure the implementation of individual production processes (milking, feeding, etc.), but also automated herd management systems $[9,10]$.

This technology makes it possible to organize a complete zootechnical and pedigree registration and form breeding groups of animals based on data on their productivity, origin and breeding value.

Thus, the herd management system is a complex hierarchical structure that monitors the ongoing processes at the dairy complex and the implementation of key technological operations.

\section{Conclusion}

1. The development of dairy cattle breeding is largely determined by the level of technical potential, the introduction of modern resource-saving equipment and technologies that ensure the receipt of competitive products.

2. A promising direction for the development of the material and technical base of dairy cattle breeding is stimulation of the innovative activity of agricultural enterprises in the implementation of advanced achievements in the field of scientific and technological progress; developments in the field of mechanization and automation, aimed at reducing unit labor costs and labor intensity of production, costs incurred and improving quality manufactured products.

3. It is necessary to modernize the material and technical base of institutions of secondary and higher agricultural education and the system of advanced training of personnel in the engineering and technical sphere by purchasing modern equipment and software products on the market to equip classrooms.

4. We consider it expedient to expand measures of state support in terms of the development of new mechanisms for the development of scientific and technological policy and modernization of the agroindustrial complex, incl. by increasing subsidies for the 
acquisition and implementation of digital and information systems, as well as wider use of leasing schemes.

5. To strengthen the ongoing research work, it is necessary to intensify work in the system of specialized institutes to create domestic information and telecommunication systems for managing technological processes in dairy cattle breeding, selection and breeding of dairy cattle.

\section{References}

1. Y.A. Ivanov, V.K. Skorkin, N.N. Novikov, Control of technological processes in dairy cattle breeding using modern computerized technology, Bull. of VNIIMZh, 1(29), 54-59 (2018)

2. Materials of the parliamentary hearings of the Committee on Agrarian Issues of the State Duma of the Federal Assembly of the Russian Federation on the topic: "Priority areas of legislative support for the development of the agro-industrial complex" (11 July 2017)

3. E.V. Truflyak, Precise animal husbandry: state and prospects (KubGAU, Krasnodar, 2018) 46 p.
4. Digital transformation of agriculture in Russia (Rosinformagrotech, Moscow, 2019) 80 p.

5. A.A. Naumenko, ed., Robotic systems in animal husbandry: textbook (KhNTUSH named after Petr Vasilenko, Kharkiv, 2015) 171 p.

6. I.A. Tikhomirov, V.K. Skorkin, Experience of using milking robots in dairy cattle breeding on the example of farms in the Kaluga region, Bull. of VNIIMZh, 1(33), 160-165 (2019)

7. N.P. Mishurov, Information management of dairy cattle breeding, Bull. of VNIIMZh, 4(16), 41-48 (2014)

8. Y.A. Tsoi, N.P. Mishurov, State and development trends of robotic equipment for milking cows, Rural machinery and equipment, 5(263), 2-9 (2019)

9. E.A. Skvortsov, E.G. Skvortsova, V.I. Nabokov, P.S. Krivonogov, Application of milking robotics in the region, Economy of the region, 13(1), 249-260 (2017) doi 10.17059 / 2017-1-23

10. A.R. Khanal, J. Gillespie, J. MacDonald, Adoption of technology, management practices and production systems in US milk production, J. of Dairy Science, 12(93) (2010) 